\title{
Corruption as Business Challenge in Pakistan
}

\author{
Yahya Khan \\ $\mathrm{PhD}$ student, 'Enterprise Theory and Practice' Doctoral School \\ University of Miskolc, Hungary \\ Gabor Rethi (PhD)
}

Senior Lecturer, Department of Entrepreneurship and Human Resources, Faculty of Finance and Accountancy, Budapest Business School, Hungary

\section{Krisztina Szegedi $(P h D)$}

Associate Professor, Department of Entrepreneurship and Human Resources, Faculty of International Management and Business Budapest Business School, Hungary

Doi:10.19044/esj.2018.v14n16p1 ～URL:http://dx.doi.org/10.19044/esj.2018.v14n16p1

\begin{abstract}
Corruption is a curse for any country, as it negatively affects the economic activities and drags the whole society to worst conditions by increasing the poverty and social inequities. Recently the most critical factor for doing business in Pakistan is corruption. In order to give a comprehensive picture of corruption in Pakistan this article (1) critically analyses the literature regarding corruption, its impact on society and the business environment specifically in Pakistan, (2) focuses on business-related factors of corruption, (3) presents various anti-corruption initiatives of Pakistani companies and foreign good examples. Based on our research this study emphasizes that the government should take corrective actions and strengthen institutions and should work in collaboration with the private and civil sector to control the uprising corruption problems. Awareness against corruption in business sphere and general public is very much needed and implementing possible anti-corruption tools, companies can positively contribute to the fight against corruption and Pakistan's economic and social development.
\end{abstract}

Keywords: Corruption, bribery, business ethics, sustainable development, corporate social responsibility, corporate responsibility, Pakistan

\section{Introduction}

'Corruption' is a word that has occupied place in print, electronic and social media which refers to a private wealth pursuing behaviour of a person who represents the state department and/or public authority, and is engaged in 
the misuse of public goods and services for his/her own private benefits. Corruption is present in different forms both in public and private sectors, such as nepotism, offering entertainments, illegal facilitation of payments, embezzlements and money laundering, fraud, bribery and gift receiving. According to the International Monetary Fund (2016) the cost of corruption is about 1.5-2 trillion USD, which is approximately $2 \%$ of global GDP. Corruption is not only an ethical issue, it can cause high human rights problems, economic uncertainty and slower down socio-economic development (Knight, 2012).

A recent survey of the World Economic Forum highlights that the most problematic factor for doing business in Pakistan is corruption (World Economic Forum, 2017, p 230). There is a very high risk of corruption in police services and in tax administration, furthermore it is high in the judicial system, in the public services sector, in land administration, in customs administration and in public procurement (GAN Business Anti-Corruption Portal, 2017). Based on the Global Corruption Barometer 2017 survey, Pakistan is the 4th most corrupt country in the Asia Pacific region. According to the survey $64 \%$ of the poorest people and $26 \%$ of the riches people in Pakistan paid a bribe based on which Pakistan is one of the countries in which bribery is more of a concern for the poor. It is not surprising that among the citizens of the 16 countries surveyed Pakistani people felt least empowered can make a difference, only 33 percent of them (Transparency International, 2017a).

The corruption in Pakistan has among others historical, ethnolinguistic and political reasons and anti-corruption efforts were less successful and the requirement of the progress is political will (Khan, 2016). According to a survey of the Transparency International - Pakistan (2017) the most relevant corruption related issues of Pakistan are nepotism/lack of merit, grand corruption, embezzlement of public funds, and tax evasion. The key point about the fight against the corruption is to understand its mechanism. This is why is important to review the literature of corruption.

\section{The theory of corruption}

"Corruption is the abuse of entrusted power for private gains" (Transparency International, 2015). Corruption is a widespread phenomenon and continues to be a moral challenge for many countries. It is commonly defined as the misuse or violation of power. Corruption is a kind of deception, which can be considered as the tendency to deceive in order to gain unfair advantage to satisfy one's needs. Deception is a common behaviour and occurs not only among humans, but also among birds, primates, and insects (Lewis \& Saarni, 1993; Ford, 1996). The shared norms of a given group can foster this behaviour in a highly competitive environment. In the wild life, the 
experienced deception has only one goal: take advantage. Human-beings are very much like animals in this view. They violate the actual order, rules of law in order to gain benefit or, at least, to perpetuate the status quo. It is a great challenge to investigate the layers of this behaviour. The issue has to some extant moved in the social, political and economic sciences as the role of state in developing world and the idea that the state is an important instrument plays vital role in economic growth and development (UNECA, 2011; Mohammed, 2013). Development depends on decent and efficient governance, accountability and necessary economic improvements. The literature often distinguishes main causes of corruption in low-income countries and highincome countries. The low-wage and poor working conditions increase the chance of corruption while in the Western (higher income levels) societies, corruption is seen as an exception rather than a habit (Caiden, 2001). Corruption is a particular illegal state-society relationship (Gbetnkom, 2012), civil servants or bureaucrats hold authoritative positions represent the state and the outsiders who are affected by corruption positively or negatively represent the society (Donwa, Mgbame, \& Julius, 2015). The act is corrupt when these state responsible personnel accept money, bribes and use their power in illegal ways to favour the suppliers i.e, businessmen, entrepreneurs or general public. Corrupt officers always try to bypass legal competition, hinder the rules of normal societal functions and influence the choices of suppliers of goods and services in the shape of new contracts or the renewal of the older ones. This state-society relationship is seldom balanced. In collective terms (Gbetnkom, 2012), corrupt practice makes the flow of recourses from the society to the state (extractive corruption) or from state to society (redistributive corruption). According to Bardhan (1997), corruption is an agency problem whereas representative of state i.e, the official performs as an agent interested to carry out the task for private gains which is difficult to monitor by the public who are acting as the principal. In most of the societies specially in developing countries people are facing severe problem of corruption, the tax officials, police inspectors, health and hygiene promoters, assistants and officers from ministries and other public departments i-e customs, electricity and gas departments, registration and processing department etc. put pressure mostly on business communities for illegal payments. Corruption is not only found in the commercial sector but it is also present in the political, judicial and even in the religious sector of public societies (Javaid, 2010). The fight against corruption is quite difficult as it is a complex phenomenon what influences both horizontally and vertically the social system. The government, non-governmental and international organizations struggle with vast power against corruption, and guidelines are formulated in the recent past, which serve to prevent bribery and unethical practices (Getz \& Volkema, 2001). However the effectiveness of these 
guidelines is questionable since the interpretation varies from culture to culture. Corruption has become a universal problem which has infected the soft atmosphere and destroyed the real structure of all the institutions in the world.

The Corruption Perception Index (CPI) of TI delivers estimations for the measurements of corruption level based on different evaluations. The scale 0-100 are used for evaluation, where 0 shows very intense level of corruption and 100 shows that country is corruption free. Data showed that corruption is an international problem, 68 percent of countries had a very severe problem of corruption; 176 countries were analysed in this survey in 2017. These problems have direct linkage and affects the people's living standards worldwide. Amongst these countries not only underdeveloped faced the problem of high level corruption but G20 countries as well. Some of the firms belonging to the most corruption-free territories also sometimes use the means of bribery to extend and increase their gains from foreign business (Transparency International, 2017b). Latest survey conducted by EY (2016) concluded that $39 \%$ of its respondents around the globe thought that bribery and corruption is present in their regions. $51 \%$ of the respondent considered that it has roots in emerging economies while $21 \%$ thought that it happens in developed markets. According to the analysis of PwC (2016) increasing country-level corruption causes decreasing GDP per capita and higher costs of doing business. The transaction costs will be higher and the risk of penalty and reputational damage will be also increasing and firms can not rely on fair competition (OECD, 2014).

\section{Corruption in Pakistan}

Corruption reveals itself in numerous forms in Pakistan including wide sphere of financial and political system, nepotism, favouritism and misuse of authority. All types like petty, moderate and grand corruption is present in the region (Chene, 2008). It was identified as the third extreme problem for companies doing business in Pakistan after poor infrastructure and government bureaucracy (Sala-i-Martin and Porter, 2008) and recently it became the most extreme factor for doing business in Pakistan is corruption (World Economic Forum, 2017, p 230).

This corruption culture is present almost in every institution i.e government or private and is deeply rooted in them. According to Awan (2004), the roots of corruption in Pakistan were found since the colonial period when the British used to give favours, lands and titles to their loyal supporters and this practice promoted the bad culture of nepotism and favouritism as a kind of corruption. The level of corruption in Pakistan is mainly high in developmental and procurement projects referred to as mega corruption, while the moderate and petty corruption is found in government offices in routine 
day to day dealings (Javaid, 2010). The most noticeable amongst them are the power sector, tax and custom, police and judiciary, land and administration and health hygiene department. Other than government offices and public sectors, corruption has also been revealed in the political sector. For participation in the elections the tickets are openly sold, and general public suffers the most from this practice because this make ineligible and uneducated persons to participate in government decision making process.

According to the surveys of the Transparency International, Pakistan ranks 117th place out of 180 countries with a score of 32 in corruption in 2017 which is very high but still Pakistan has shown better results in corruption control in the previous five years as compared to 2012 where Pakistan was ranked 139th with a score of 27 (Transparency International, 2018).

Figure 1. Corruption rank and score of Pakistan 2012-2017

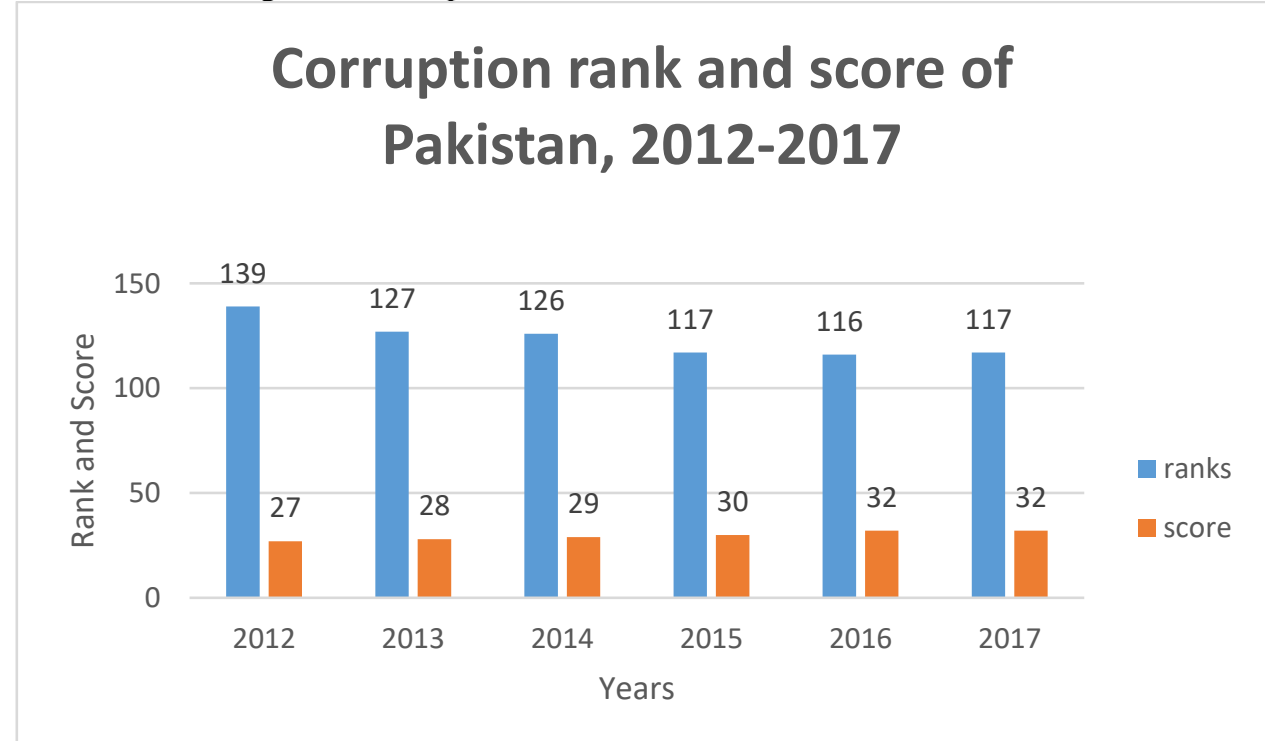

Source: Created by the authors based on Transparency International (2018): Corruption Perception Index

In the Enterprise Surveys business owners and top managers in 1,247 firms in Pakistan were interviewed from May 2013 to May 2015 in order to evaluate the key factors that shape the business environment. $68.3 \%$ of the Pakistani firms identified corruption as a major constraint. The table 1 summarizes key indicators at the country and regional levels for corruption. The most problematic issue is government contracts: $88.2 \%$ of the firms were expected to give gifts to secure government contract. The value of gift expected to secure a government contract was $8.2 \%$ of the contract value which is higher than the same in South Asia (2.9\%) or the average of all countries (1.8\%) (World Bank, 2015). 
Table 1. Indicators of corruption faced by Pakistani firms

\begin{tabular}{|l|c|c|c|}
\hline Indicator & Pakistan & South Asia & All Countries \\
\hline Bribery incidence (percent of firms experiencing at least one bribe payment request) & 30.8 & 24.8 & 18.0 \\
\hline Bribery depth (\% of public transactions where a gift or informal payment was requested) & 28.5 & 21.0 & 14.0 \\
\hline Percent of firms expected to give gifts in meetings with tax officials & 28.8 & 19.6 & 13.0 \\
\hline Percent of firms expected to give gifts to secure government contract & 88.2 & 45.5 & 29.4 \\
\hline Value of gift expected to secure a government contract (\% of contract value) & 8.2 & 2.9 & 1.8 \\
\hline Percent of firms expected to give gifts to get an operating license & 31.0 & 25.3 & 14.3 \\
\hline Percent of firms expected to give gifts to get an import license & 6.0 & 27.4 & 14.4 \\
\hline Percent of firms expected to give gifts to get a construction permit & 28.7 & 30.9 & 23.2 \\
\hline Percent of firms expected to give gifts to get an electrical connection & 57.8 & 37.3 & 16.2 \\
\hline Percent of firms expected to give gifts to get a water connection & 30.9 & 36.7 & 16.2 \\
\hline Percent of firms expected to give gifts to public officials "to get things done" & 45.8 & 25.5 & 22.5 \\
\hline Percent of firms identifying corruption as a major constraint & 68.3 & 40.1 & 32.6 \\
\hline Percent of firms identifying the courts system as a major constraint & 34.6 & 16.8 & 14.5 \\
\hline
\end{tabular}

Source: Created by the authors based on World Bank (2015): Enterprise Surveys. Pakistan Country Profile, 2013.

Corruption has also affected badly further factors of the business ethics in Pakistan. Malpractices in the registration of new businesses, black marketing, poor quality product production and tax heisting are some of its forms by individual businessmen and business firms. Although the government has implemented certain policies regarding stopping these practices but the insider corrupt officials make it difficult to fight against it in an efficient manner. Almost all spheres of activities have been polluted by intense corruption in different shapes thus the whole society is facing problems in a social framework.

Corruption and bad governance slows down the economic growth and negatively affects the development of private sector. Gohar et.al (2012) analysed the impacts of corruption on foreign direct investment (FDI) in Pakistan and found that corruption has negative relationship with FDI and thus it amplifies the uncertainty linked with investment opportunities. The study showed that corruption results in discouraging the Multinational Companies to invest in the region. FDI is the backbone of any economy and plays a vital role in the economic growth of a region. The slow pace of FDI in Pakistan as compared to other developing countries is a big threat to its economic development. Policy makers need to work hard and make important decisions regarding the control and better implementation of the policies against corruption.

There are a lot of corruption cases in Pakistan since it independence in 1947 but the most prominent in the last decade are (1) The famous case of corruption regarding privatization of Pakistan Steel Mills (PSM) in President 
Musharraf's regime, Farooq (2006) asserted that the Musharraf Government has sold the PMS of total worth 5 billion US\$ for 362 million US\$. The consortium of three companies participated in the bidding process were Arif Securities (Pakistan), Magnitogrosk Iron and Steel Work open JSC a Russian company and Al-Tuqwairqi a (Saudi firm). Latter on Pakistan Supreme Court took Suo Moto action and stopped the privatization of PSM. (2) Declan Walsh, investigative journalist in New York Times unveiled a Pakistani Software Company named Axact involved in issuing fake degrees around the world. The company was involved in taking money from almost 215000 people from 197 countries and earned at least 89 million US\$ in its final year from these illegal operations (Dawn News, 2016). (3) Khani and Kali money laundering case according to Hussain (2015) The Federal Investigation Agency (FIA) Submitted a charge of money laundering against Javeed Khanani, involved in transferring 140 million Pakistani rupees to other countries by violating business rules in 2008 .

\section{Causes and Impacts of Corruption}

In an effective state, rules and institutions are important for providing goods and services in a productive way which gives an opportunity to people to lead a healthier and prosperous life. Without it, a sustainable social and economic development is impossible (World Bank, 1997). Due to the absence of strong states and private institutions, corruption has severely affected common man's life through less returns on recourses and higher cost of living. It is a global issue but intensively spread in the developing and underdeveloped countries because the conditions and system favours it.

The smaller portion of public expense to education, health and greater portion to public investment especially in non-productive projects decreased the output of the available stock of capital and promoted the corruption (Tanzi and Davoodi, 1997). The level of corruption in a community rests on the value and morals of the society (Vittal and Mahalingan, 2004). In developing countries like Pakistan the culture of bribery serves as an incentive for the government employees, the main reason is their low salaries and high household expenditures. Sometimes it pulls down the transaction cost and saves the time of supplicants. One of the reasons for corruption is the high level of inequalities in the society (Yolles, 2008). According to (Ahmed, 2011), there is a direct relationship between poverty and the level of corruption. In Pakistan where each of the landed dollars is supposed to be spent to increase the living standards of the common people but unfortunately a significant part of it is lost due to the unethical practices like bribery and nepotism. Such activities are found all over Pakistan mainly in the rural areas of Sindh and Baluchistan in severe form and the reasons behind this are lack of education, extreme poverty, a non-existent or destroyed infrastructure and 
the misuse of power. Other causes of corruption are the lack of accountability, loose rules and regulations and weak supervision of the policies against it. It is difficult to sort out the whole causes of corruption but yet in 2009 National Corruption Perception Survey (NCPS) was conducted under the supervision of Transparency International Pakistan and enlisted main reasons which contributed towards corruption in terms of percentage (NACS, 2009). According to the survey, the main reasons are lack of accountability, lack of transparency, discretionary power, monopoly of power, low salaries, strongdemand and supply, power of influential people, and red tape.

Rahman (2011) emphasized as ten main causes of corruption in Pakistan the followings: (1) abuse of power by the public office holders; (2) political leaders' incompetence; (3) poorly paid salary structure in the public sector; (4) lack of transparency; (5) absence of adequate internal/external controls to prevent bribery; (6) poor legislative accountability is consistently a problem and runs the risk of hindering prospects for enacting long-term Anticorruption reforms; (7) weaknesses in the judicial system; (8) illiterate and ignorant populace with inadequate public discernment of political choices; (9) power of influential people; (10) lack of serious programme of combating corruption in the country.

Corruption can shrink the effectiveness and efficiency of a region on which its economy depends and it also puts an upwards pressure on the cost of investment which in turn lowers down the returns. In Pakistan like other developing countries corruption is increasing day by day and often encouraged rather than discouraging as the institutions, departments and system fighting against it are weak by themselves (Ismail et. al, 2010). The future of Pakistan and its efforts fighting against poverty are totally reliant on the successful and fruitful completion of its developmental projects (Ahmed, 2011), and it is possible only when the evil practice of corruption is controlled.

Along with social impacts like low living standards, increased unemployment, lower level of education and healthcare facilities corruption may also be responsible for the reduction in efficiency of individual firms because it may compel the firm to indulge itself in a number of non-productive expenses which affect its performance in allocating and assessing the resources. This also discourages newly formed small and medium enterprises as they avoid themselves to be involved in illegal activities, are afraid of its future consequences like audit, inspections and mostly they are more aware of the firm's goodwill which is important for their upcoming profits and sustainability in general. Johnson et.al (1998) asserted that corruption distorts the progressive development of small and medium enterprises and supports the emergence of underground economy. Farooq, and his co-authors examined long run relationship between corruption and economic growth based on 
Pakistani data between 1987 and 2009. They found that corruption hampers economic growth (Farooq et al. 2013).

\section{Best Anti-Corruption Practices}

There are several initiatives against corruption at country and organisation level as well. According to Stefanuc (2011), in June 2011 the European Commission agreed on an anti-corruption package which addressed new documents and approaches to corruption at EU level. The main uniqueness of this package lies in shaping an anti-corruption reporting mechanism to assess the EU member States on regular basis regarding their efforts against corruption. It further asserted that EU member countries as compared to other countries around the world are less corrupt. EU corruption cost is at least $1 \%$ of GDP per annum. It has become vivid that the impact of corruption goes outside the country boundaries and it cannot be combated in isolation, a collective measure should be taken against it.

Chene (2011) a senior research coordinator at TI mentioned that New Zealand, Finland, Sweden and Denmark beside high GDP per capita, lesser inequalities, higher literacy rate (almost 100\%), law enforcement and strong obligations to policies against corruption by their political leaders, the freedom of media and press, transparency mechanism "disclosure of information" and public participation in the fight against corruption showed a positive relationship with corruption control.

Government and their policies can play an important role in corruption control. Liu and Lin (2012) conducted a study and found that there is a positive relationship between irregularities in government audit system and corruption.

Private sector is more responsible for breeding corruption as compare to public sector and caused more harms to the economy (Puccio, 2013) so private organizations have an important role in corruption control. According to Windsor (2014), successful, effective and efficient governance and anticorruption actions hinge on the personal integrity of business directors and executives. Maria, et.al (2009) asserted that initiatives of private companies towards the best practices of corporate governance like ethical leadership, employee commitment to the company code of conduct, fairness in procurement, marketing, production and human resource management can really improve the organizational environment against corruption. Strong and unbiased relationship between company and stakeholders, introduction of more transparency, communication and devotion to the company ethics and code of conduct is necessary for the reduction of corruption.

The UN Global Compact (UNGC) anti-corruption principal (principal 10) tells us "Business should work against corruption in all its forms, including extortion and bribery" (Windsor, 2014). The large multinational companies having a recognizable brand, millions of consumers across the globe, are 
responsible to implement maximum ethical standards and best polices against bribery and corruption. According to Coca-Cola Company they have enforced anti bribery policy (globe) which helps them to control the bribery of local and foreign government official as well as in the commercial sector. This policy is based on US Foreign Corrupt Practices Act "FCPA" and UK Bribery Act 2010 "UKBA". Any violation of these laws result in strict disciplinary action including civil and criminal penalties.

According to Transparency International while assessing the world's largest companies (2014), the companies are supposed to prohibit the facilitation payments. They should disclose all of their political donations, list of their subsidiaries, joint ventures and other bodies. The companies must publish publically their financial accounts for each region where they are operating. Transparency international conducted a survey in 2014 to assess the level of transparency of world's largest companies. Their performance was measured in three categories: (1) Anti-corruption programs; (2) organizational transparency; (3) country by country reporting. According to this report, 101 companies score less than 5 out of 10 overall. 7 out 10 companies were from Europe in best performance. 8 out of 10 companies were from Asia in worst performance. Only Vodafone (UK) achieved 50\% in all three categories. In the category e,g. Anti-corruption programs Vodafone secured the highest percentage of $100 \%$ followed by Anheuser-Busch InBev (Belgium), BG Group (UK), Eni (Italy), British Tobacco (UK), Gilead Services (USA), Hewlett-Packard (USA) and Proctor and Gamble (USA) got 96\%. One the other hand Bank of China scored the lowest among all the companies 4\% followed by Agriculture Bank of China and China Construction Bank with 15\% (Transparency International, 2014).

International Standard Organization (2016) made some improvements in the anti-bribery system that are known as ISO 37001:2016, provides guidance regarding anti-bribery management system which might stand alone or unified into over management system of the firm. These guidelines are applicable to all organization irrespective of the size, type, nature of the operation and practices. Fraud, money laundering or other same activities in accordance with corruption practices are not specifically addressed but the organizations have a choice to broaden the scope of the management system by including such activities. ISO 37001:2016 addresses organizational activities which not only includes the bribery by the organization but also addresses the bribery by personnel, business associates or by a third party on behalf of the organization or for its own benefits (International Organization for Standardization, 2018).

Partnering against corruption initiative (PACI) working with international firms, business personnel's and governments in order to address the problems of corruption and transparency was initiated in 2004 by CEOs of 
world economic forum. The world economic forum provides a platform through PACI to shape agendas against corruptions and motivates the CEOs to participate in activities which help to combat corruption (PACI overview, 2017). The member organizations of PACI are committed to show zero tolerance to corruption in all its forms, and take actions to develop, and increases the public trust in the organization's business. Some of the member firms such as Coca-Cola Company, Unilever, Royal Dutch Shell, Royal Philips, Deloitte, Consolidated Construction Companies, BASF, Siemens, Marriot International, Standard Charter Bank, Glaxo Smith Kline (GSK), Thomson Reuters, Crescent Group Limited and Deutsch Post DHL has their subsidiaries in Pakistan (World Economic Forum, 2018).

\section{Anti-corruption Activities in Pakistan}

Corruption is one of the most destroying element for any country. Muhammad Ali Jinnah the founder of Pakistan in his very first speech to the first Constituent Assembly on 11 august 1947, he said "One of the biggest curse from which India is suffering - I do not say that other countries are free from it, but I think our condition is much worse- is bribery and corruption. That is a poison. We must put that down with an iron hand and I hope you will take adequate measures as soon as it is possible for this Assembly to do so" (Jinnah,1947). The legal framework for addressing corruption includes the Pakistan Penal Code 1960 and Prevention of Corruption Act 1947 followed by National Accountability Bureau Ordinance 1999 (NAO). This ordinance is the most detailed legislation till date in Pakistan against corruption and other illegal activities. In 1999 under this ordinance the National Accountability Bureau (NAB) came into existence and gave exceptional range powers to NAB in "effective measure for detection, investigation, speedy disposal of cases related to corruption, corrupt practices, misuse or abuse of power" (NAO,1999). According to the annual report of NAB (2015) total 29996 complaints were received at the headquarter and 596 persons were found guilty and agreed to pay 7157.393 million Pakistani Rupees on account of voluntary returns. Total cumulative recoveries made by NAB in 2015 were 12.097 billion Pakistani Rupees.

National Anti-corruption strategy (NACS) based on National Integrity System (NIS) was formed by NAB in 2002, the stake holders include business societies, academia, public and civil societies were involved in the research process and formulation of the strategy. The main aim of the NACS was to bring awareness against corruption and make its deterrence possible (NIS country report). The awareness campaign has main focus on the educational sector and media i.e, social and print media. These campaigns vary from poster competition among students to public debates on corruption (Hafiez, 2005). 
There are certain other departments active against corruption in Pakistan which includes auditor general responsible for strengthening and concentrate on the financial audit functions. The ombudsman (Wafaqi Muhtasib) established in 1983 by presidential orders. The main role of this institution is to investigate and compensate all those who bear losses and damages due to poor administration of government officials. The Public Procurement Regulatory Authority (PPRA), supervise the public procurements and make sure the implementation of Public Procurement Rules 2004 in all procurement agencies. The Federal Investigation Agency (FIA) found in 1974 under the FIA Act 1974. It's Anti-Corruption and Economic Crime Branch is active against Corruption. (U4 Expert Answer Report, 2015).

It is not possible to eradicate the problem of corruption overnight but certain measures should be taken collectively by the state and its stakeholder's mainly general public to shake off the tag of corruption and accelerate the country towards prosperity. According to Javaid (2010), good governance is a necessary ladder to meet the corruption problem. The awareness in common man and the emergence of educated civil society, independent media and strong judiciary system can work effectively against it and ensure its success in social and economic development. Corruption may be controlled through successful implementation of some strict monitoring procedures and measures (Khan et. al, 2004). Anti-corruption laws can promote and provide a platform for more structural reforms (Rose Ackerman, 1999), and help to make the commission to work as an independent body. Accountability should be confirmed at any level of management from top to bottom. Independent private sector auditors must be encouraged. Each and every government official along with politicians must require to declare their assets and other sources of income. Awareness campaigns are necessary to be launched in general public especially amongst students. Policies for poverty eradication and economic expansions must be ensured (Hussain and Hussain, 1993) like encouraging government officials against corruption by providing incentives, allocation of appropriate amount of funds to education, health care facilities and focus on the living standards of people. Government should encourage people towards small and medium enterprises and provide financial assistance in a proper manner. Hiring of new employees on merit, supremacy of law and strengthening of institutions must be ensured by the state.

Civil organisations and businesses play an important role in the fight against corruption. 
Table 2. Global Compact participant companies from Pakistan

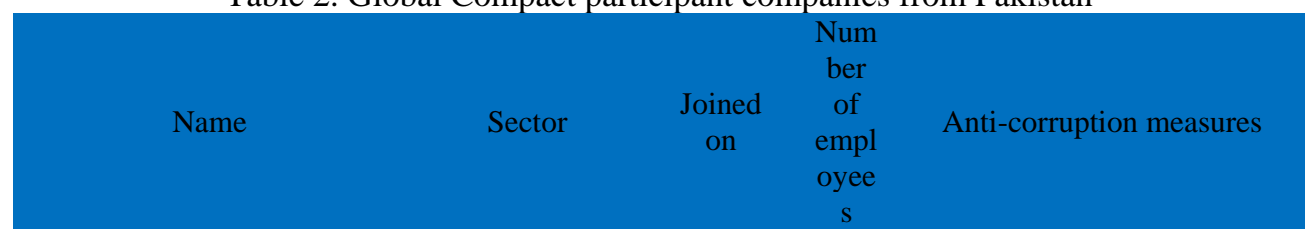

HASCOL Petroleum Ltd

SUI Northern Gas Pipelines Limited

Sadaqat Limited

Herbion Pakistan (Pvt) Limited

Pakistan State Oil

Haris Enterprises (Pvt.) Ltd.

Bulleh Shah Packaging

Hi-Tech Lubricants Limited

Pak Oasis Industries (Pvt.) Ltd.

Saita (Pakistan) Pte. Ltd.

Shakarganj Mills Limited
Oil Equipment, Services \& Distribution

Oil Equipment, Services \&

Distribution

$05-19$

$2017-$

05-30

680

Commitment to fair dealing, prohibition of accepting Gifts and Entertainments, Information sharing with external suppliers and customers, avoid misrepresentation of products, services and prices Actions anginst misconducts, scrutiny and accountability, Internal audit and prohibition of receiving gifts

Risk assessment, internal

Diversified $\quad \begin{aligned} & 2016- \\ & 11-22\end{aligned}$

5000 audit, mentioned in business partners contracts

Risk assessment, zeo

Pharmaceuticals 2016\& $\quad 2016$

Biotechnology

$08-18$

Oil Equipment,

2016Services \& $06-28$

Distribution

$2015-$

$\begin{array}{ll}\text { Support } & 2015 \\ \text { Services } & 11-30\end{array}$

1800

Forestry \& 2013Paper 11-07

Oil Equipment, Services \&

$2013-$ Distribution

05-13

Industrial

2012-

Engineering

08-28

Construction \&

2010Materials

08-30

2010Food Producers 08-27
400

1200

500

tolerance, Mentioned in contracts with business partners, internal audit

Whistle blowing, Business principle and ethics policy, risk based audit of business functions

Anti bribery and corruption policy

Zero tolerance, risk assessment, awareness

1000 sessions, whistle blowing procedure, ethics compliance committee

Code of conduct, AntiCorruption check system, listing all gifts gifts are prohibited, prohibition of gambling at work, independent investigation,

Zero tolerance to curroption, bribery and extortion, prohibition of receiving gifts, declaration of employees assets, trainings

Risk assesment, zero tolerance, policy against bribery, embezzlement, money laundering and obstruction of justice, fair dealings 


\begin{tabular}{|c|c|c|c|c|}
\hline $\begin{array}{l}\text { Fauji Fertilizer Company } \\
\text { Limited }\end{array}$ & Chemicals & $\begin{array}{l}2010- \\
03-23\end{array}$ & 2730 & $\begin{array}{l}\text { Code of conduct and laws, } \\
\text { zero corruption policy, risk } \\
\text { assesment, whistle blowing, } \\
\text { communication and trainings }\end{array}$ \\
\hline $\begin{array}{l}\text { Pak-Arab Refinery Limited } \\
\text { (PARCO) }\end{array}$ & $\begin{array}{l}\text { Oil \& Gas } \\
\text { Producers }\end{array}$ & $\begin{array}{l}2010- \\
03-05\end{array}$ & 1400 & $\begin{array}{c}\text { Risk assesment, transparency } \\
\text { on top priority, internal } \\
\text { audit, HR policy against } \\
\text { bribery, extortion and } \\
\text { misconducts. }\end{array}$ \\
\hline Attock Refinery Limited & $\begin{array}{l}\text { Oil \& Gas } \\
\text { Producers }\end{array}$ & $\begin{array}{l}2008- \\
01-25\end{array}$ & 898 & Zero tolerance, training \\
\hline Hinopak Motors Limited & $\begin{array}{l}\text { Automobiles \& } \\
\text { Parts }\end{array}$ & $\begin{array}{l}2006- \\
06-22\end{array}$ & 973 & $\begin{array}{l}\text { Code of conduct, whistlre } \\
\text { blowing system, risk } \\
\text { assessment, independent } \\
\text { audit, vendor Pre- } \\
\text { qualification }\end{array}$ \\
\hline $\begin{array}{l}\text { International Industries } \\
\text { Limited }\end{array}$ & $\begin{array}{l}\text { Construction \& } \\
\text { Materials }\end{array}$ & $\begin{array}{l}2006- \\
06-22\end{array}$ & 1367 & $\begin{array}{l}\text { Code of conduct, "Speak } \\
\text { Up" policy }\end{array}$ \\
\hline Hashwani Hotels Limited & $\begin{array}{l}\text { Travel \& } \\
\text { Leisure }\end{array}$ & $\begin{array}{l}2006- \\
06-12\end{array}$ & 1741 & $\begin{array}{l}\text { Zero tolerance, code of } \\
\text { conduct, audit, supplier } \\
\text { principles, anonymous } \\
\text { complaint boxes, training }\end{array}$ \\
\hline Agriauto Industries Limited & $\begin{array}{l}\text { Automobiles \& } \\
\text { Parts }\end{array}$ & $\begin{array}{l}2006- \\
04-04\end{array}$ & 615 & $\begin{array}{l}\text { Code of ehics and statement } \\
\text { of compliance, in SAP } \\
\text { properly recorded financial } \\
\text { activity, centralized } \\
\text { procurement activity }\end{array}$ \\
\hline Al-Ghazi Tractors Ltd. & $\begin{array}{c}\text { Industrial } \\
\text { Engineering }\end{array}$ & $\begin{array}{l}2006- \\
04-04\end{array}$ & 433 & Commitment, code of ethics \\
\hline Pakistan Cables Limited & $\begin{array}{l}\text { Construction \& } \\
\text { Materials }\end{array}$ & $\begin{array}{l}2006- \\
04-04\end{array}$ & 599 & $\begin{array}{l}\text { Not supporting political } \\
\text { party, transparent diclosure, } \\
\text { gambling at work is } \\
\text { prohibited, using company } \\
\text { resorurces for private gain is } \\
\text { not permitted }\end{array}$ \\
\hline Pakistan Petroleum Limited & $\begin{array}{l}\text { Oil \& Gas } \\
\text { Producers }\end{array}$ & $\begin{array}{l}2006- \\
04-04\end{array}$ & 3000 & $\begin{array}{c}\text { Code, of conduct, zero } \\
\text { tolerance, prohibition of } \\
\text { gifts, declaration about } \\
\text { empoyees assets on a yearly } \\
\text { basis. }\end{array}$ \\
\hline $\begin{array}{l}\text { Tourism Promotion } \\
\text { Services (Pakistan) Limited }\end{array}$ & $\begin{array}{l}\text { Travel \& } \\
\text { Leisure }\end{array}$ & $\begin{array}{l}2006- \\
04-04\end{array}$ & 1171 & $\begin{array}{c}\text { Code of conduct, zero } \\
\text { tolerance }\end{array}$ \\
\hline Indus Motor Company & $\begin{array}{l}\text { Automobiles \& } \\
\text { Parts }\end{array}$ & $\begin{array}{l}2006- \\
02-21\end{array}$ & 2849 & $\begin{array}{c}\text { Code of conduct, internal } \\
\text { audit, risk assessment, } \\
\text { training, }\end{array}$ \\
\hline $\begin{array}{c}\text { Rastgar Engineering } \\
\text { Company Private Limited }\end{array}$ & $\begin{array}{l}\text { Automobiles \& } \\
\text { Parts }\end{array}$ & $\begin{array}{l}2006- \\
02-20\end{array}$ & 400 & $\begin{array}{l}\text { Commitment, Independent } \\
\text { Audit Committee, Vendor } \\
\text { Policy }\end{array}$ \\
\hline Engro Corporat & $\begin{array}{l}\text { General } \\
\text { Industrials }\end{array}$ & $\begin{array}{l}2005- \\
06-13\end{array}$ & 3500 & $\begin{array}{c}\text { Commitment, SpeakOut } \\
\text { policy, Internal audit }\end{array}$ \\
\hline
\end{tabular}

Source: Created by the Authors based on Transparency International (2018b).

Transparency International- Pakistan (2017) elaborated a new Strategic Plan through which it would like to promote a corruption free system 
of governance, politics and business. The main strategic goals are the following:

(1) Citizens become more aware of their rights and reject corruption.

(2) Selected Public/Private Sector adopts anti-corruption measures in their practices.

(3) Evaluate existing laws, highlight weaknesses, give recommendations, and advocate stricter implementation.

(4) Promoting integrity in current and future leaders of Pakistan.

(5) TI Pakistan regarded a focal point for transparency and anti-corruption measures.

\section{Conclusion}

The literature survey in this paper shows that corruption is not only the problem of developing countries but also the developed countries are facing it severely. Corruption is a calamity and a hurdle in the socioeconomic development of the whole world. The intensity of corruption affects positively the level of income-inequalities and poverty in the society (Gupta et.al, 1998). Pakistan is also confronting the problems of corruption like other developing countries in both state and private sectors. Corruption is not only found in government offices, procurement and developmental projects, power sectors etc. but also witnessed in the practices of private organizations. This research shows that corruption is deeply rooted in the whole system of the country which is fatal for both national economy as well as for the reputation in the international markets. Along with general social aspects of corruption, this study also focuses specifically on its effects on the business environment of Pakistan. Small and medium business enterprises (SMEs) play a role of engine in the economic development of any country (Beck and Asli, 2006). Illegal practices in any form has a negative impact on the development of SMEs. It not only affects SMEs but also one of the reasons which reduces growth, employment and production (Kanu, 2015). Corruption has increased the cost of firm expansion and contributes as barrier in the development of small and medium business enterprises in Pakistan (Bari et al, 2005). It is necessary for the government to develop strict polices and also strengthen the institutions, engage in eradication of corruption by making them independent and enhance their powers. Government, private organization and businesses (SMEs and MNCs) should initiate more anti-corruption programs because these activities reduce not only the corruption and poverty but also increase the quality of public interest and income growth (Chetwynd et.al, 2003). The overall conclusion of this paper is that the reduction of corruption will increase business activities in the region along with the social development and lead the nation towards economic prosperity. 


\section{References:}

1. Ahmad. S (2011), "Impact of Corruption on our Society", The Nation, August, 2011.

2. Awan Malik.B (2004), "Anti-corruption: Strategies in Pakistan", Lahore: Book Biz.

3. Anti- Bribery Policy and Compliance Hand book (2012), Coca-Cola Company.

4. Awan Malik.B (2004), "Anti-corruption: Strategies in Pakistan", Lahore: Book Biz.

5. Bardhan, P (1997), "The Economics of Corruption in Developing Countries: A review of the Issue", Journal of Economic Literature,35(3)September.

6. Bari,.F et.al (2005), "SME's Development in Pakistan: Analyzing the Constrains to Growth", Asian Developing Bank, Working no.3.

7. Beck, T and Asli, D (2006), "Small and Medium Size Enterprise: Access to Finance as a Growth Constrain", Journal of Banking and Finance, vol.30.

8. Caiden, G. E. (2001). Dealing with Administrative Corruption. In T. L. Cooper (Szerk.), Handbook of Administrative Ethics (old.: 429455). New York: Marcel Dekker.

9. Cheine, M (2008), "Overview of Corruption in Pakistan", www.U4.no/helpdesk/helpdesk/quary.cfm?id=174.

10. Chene, M (2011), "What makes New Zealand, Denmark, Finland, Sweden and other "Clearer" than Most Countries?" Transparency International the Globe Collation against Corruption. http://blog.transparency.org/2011/12/07/what-makes-new-zealanddenmark-finland-sweden-and-others\%E2\%80\%9Ccleaner\%E2\%80\%9D-than-most-countries/.

11. Chetwynd, E et.al (2003), "Corruption and Poverty: A Review of Recent Literature", www.eldis.org/vfile/upload/1/0708/Doc14285.pdf

12. Dawn (2016), "Axact Fraud Empire Bigger than Initially ImaginedNYT Report Detailed News Revelation", April 2016. http://www.dawn.com/news/1251429.

13. Donwa, P.A., Mgbame, C.O., and Julius, O.M. (2015), "Corruption in the Oil and Gas Industry: Implication for Economic Growth", European Scientific Journal, (11) 22, 212-230

14. EY (2016). Corporate misconduct. Individual consequences. $14^{\text {th }}$ Global Fraud Survey. London: EYGM Limited.

15. Farooq, A. - Shabbaz, M. - Arouri, M. - Teulon, F. (2013): Does corruption impede economic growth in Pakistan? Economic Modelling 35 (2013) 622. DOI: 10.1016/j.econmod.2013.08.019 
16. Farooq, T (2006), "The Corruption In Pakistan Steel Mills Case", Europe Solidaries Sans Frontiers. May 2006. http://www.europesolidaire.org/spip.php?article2411.

17. Ford, C. V. (1996). Lies! Lies!! Lies!!! The Psychology of Deceit. Washington, DC: American Psychiatric Press, Inc.

18. GAN Business Anti-Corruption Portal (2017): Pakistan Corruption Report. https://www.business-anti-corruption.com/countryprofiles/pakistan (Downloaded: 2018. 02. 18.)

19. Gbetnkom, D (2012), "Corruption and small and medium Sized enterprises growth in Cameroon"African Conference 2012.

20. Getz, K. A., \& Volkema, R. J. (2001). Culture, Perceived Corruption, and Economics. A Model of Predictors and Outcomes. Business \& Society, 40(1), 7-30.

21. Gohar, R et.al (2012), "the Effect of Corruption on Country-level Investment: The Case of Pakistan", Fraud Cases from Emerging Economies: PP 133-145.

22. Gupta, E et.al (1998), "Does corruption Affect Income Inequalities and Poverty?", IMF working paper,WP/98/76

23. Hafiez. M (2005), "Turning Pakistan into a true Blue Chip", The Blue Chip, vol.2 (14)PP17-24.

24. Hussain, M. and Akmal, H (1993), "Pakistan: Problems of Governance, Lahore, Vanguard Book.Pvt.LTD.

25. Hussain, Z.A (2015), "FIA Nominates Javed Khanani in Money Laundering case", The News. January 2015.

26. International Organization for Standardization (2018): ISO 37001:2016 Anti-bribery management systems -- Requirements with guidance for use https://www.iso.org/standard/65034.html

27. Ismail et. al (2010), "Some Issues of government in Pakistan", www.spcdc.org.pk/pubs/cp/cp39.pdf.

28. Javaid. U. (2010), "Corruption and its deep impact on Good Governance in Pakistan", Pakistan Economic and social Review: Volume 48.1.

29. Jinnah. M (1947), "Speech to the constituent Assembly",Press release by NAB in November2016,University of Qauaid-Azam.

30. Johnson, S et.al (1998), "Regulatory discretion and the Unofficial Economy", American Economic Review,88(2).

31. Kanu, A.M (2015), "The Effects of Corruption on Small and Medium Enterprises: Perspective From a Developing Country", International Journal of Small and Medium Businesses and Entrepreneurship Reserch,Vol.3. 
32. Khan, F. (2016): "Combating corruption in Pakistan”, Asian Education and Development Studies, Vol. 5 Issue: 2, pp.195-210, https://doi.org/10.1108/AEDS-01-2016-0006

33. Khan, M et.al (2004), "Prosecuting Corruption: The Case of Pakistan”, Ethics Forum, American Society for Public Administration,26-27, March 2004.

34. Knight, J. (2012), “The Economic Causes and Consequences of Social Instability in China", CGC Discussion Paper Series.

35. Lewis, M., \& Saarni, C. (szerk.). (1993). Lying and Deception in Everyday Life. New York: The Guilford Press.

36. Liu, J. and Lin, B. (2012), "Government Auditing and Corruption Control: Evidence from China's Provincial panel data”, China Journal of Accounting Research,PP163-186.

37. Maria, V. et.al (2009), “Transparency To Reduce Corruption?”, Journal of Business Ethics.PP373-385.

38. Mohammed, U. (2013), "Corruption in Nigeria: A Challenge to Sustainable Development in the Fourth Republic", European Scientific Journal, (9) 4, 118-137

39. National Accountability Ordinance "XVIII of 1999" (1999), www.oecd.org/site/adboecdanti-corruptioninnitiative/46816815.pdf.

40. National Anti-Corruption Strategy Report (2002), National Accountability Bureau, Government of Pakistan.

41. Puccio, F.G. (2013), "Corruption and Private Sector: A review of Issue, EPS-PEAKS.

42. PwC (2016): Global Economy Watch. May 2016 https://www.pwc.com/gx/en/issues/economy/global-economywatch/assets/pdfs/global-economy-watch-may-2016.pdf (Downloaded: 2018. 02. 18.)

43. Rahman, Saeed (2011): Issues in Governance: Revisiting the Root Causes and Impacts of Corruption and Mismanagement. ISSRA $\begin{array}{lll}\text { Papers Vol3 Issue } & \\ \text { http.//www.ndu.edupk/issra/issra pub/articles/issra- }\end{array}$

http://www.ndu.edu.pk/issra/issra_pub/articles/issrapaper/ISSRA_Papers_Vol3_IssueI_2011/01-ISSUES-IN-

GOVERNANCE-Saeed-ur-Rehman.pdf (Downloaded: 2018. 02. 18.)

44. Rose-Ackerman, S. (1999), "Corruption and Government", UK: Cambridge University Press.

45. Sala-i-Martin,.X, and Michael, P. (2008), "The Global Competitiveness Report 2007-2008, www.gcro7.weforum.org.

46. Stefanuc, R. (2011), "Corruption, or How to Tame the Shrew with the European Union Strick: The New Anti-corruption Initiative of the European Commission" ERA Forum, PP427-443. 
47. Tanzi, V., and Davood, H. (1997), “Corruption, Public Investment and Growth" IMF working paper.97/139, Washington,IMF.

48. Transparency International - Pakistan (2017): Strategic Plan 2017 2020 Action Plan for Transparency and Accountability. http://www.transparency.org.pk/pdf/TI-P_Strategy_2017-2020.pdf

(Downloaded: 2018. 02. 18.)

49. Transparency International (2014), "Transparency in Corporate Report: Assessing the world largest companies".

50. Transparency International (2015a). What is Corruption? Retrieved July 12, 2016 from http://www.transparency.org/what-is-corruption/\#define

51. Transparency International (2017a): People and Corruption: Asia \begin{tabular}{llll}
\hline Pacific & Global & Corruption & Barometer.
\end{tabular} https://www.transparency.org/whatwedo/publication/people_and_corru ption_asia_pacific_global_corruption_barometer_(Downloaded: 2018. 02. 18.)

52. Transparency International (2017b): Corruption Perception Index 2016. https://www.transparency.org/news/feature/corruption_perceptions_in dex_2016\#table (Downloaded: 2018. 02. 18.)

53. Transparency International (2018a): Corruption Perception Index 2017. https://www.transparency.org/country/PAK (Downloaded: 2018. 03. 03.)

54. Transparency International (2018b): Our Participants. https://www.unglobalcompact.org/what-is-gc/participants (Downloaded: 2018. 03. 03.)

55. Transparency International Pakistan (2009), "National Corruption Perception Survey TI Pakistan”. www.transparency.org.pk/documents/NCPS\%202009/NCPS\%20200 9\%20\%20Report.pdf.

56. Transparency International-Pakistan (2014), "National Integrity System, Country Report".

57. U4Expert answer Report (2015), "Pakistan: overview of Corruption and Anti-corruption Efforts", www.u4.no/publicstion/Pakistan-overview-of - corruption-and-anti-corruption-efforts/.

58. United Nation Economic Commission for Africa (2011), "Economic report on Africa".

59. Vittal, N., and Mahalingan, S. (2004), "Fighting Corruption and Restructuring Government. NewDelhi: Manas Puublication.

60. Windsor, D. (2014), "Corporate Governance as an Antidote to Corruption in Emerging Markets",CSR, Sustainability, Ethics and Governance, PP423-444.

61. World Bank (1997), "World Development Report”. 
62. World Bank (2015): Enterprise Surveys. Pakistan Country Profile, 2013.

http://www.enterprisesurveys.org/data/exploreeconomies/2013/pakist an\#corruption (Downloaded: 2018. 02. 18.)

63. World Economic Forum (2017): The Global Competitiveness Report 2017-2018. Geneva, ISBN-13: 978-1-944835-11-8. http://www3.weforum.org/docs/GCR20172018/05FullReport/TheGlobalCompetitivenessReport2017\%E2\%80 \%932018.pdf (Downloaded: 2018. 02. 18.)

64. World Economic Forum (2018): PACI (2018): Partnering against Corruption Initiative https://www.weforum.org/communities/partnering-againstcorruption-initiative (Downloaded: 2018. 02. 18.)

65. Yolles, M. (2008), "A Social Psychological basis of Corruption and Sociopathology. In De Lucca, Federico N. (ed)", Economic Corruption Detection, Costs and Prevention, New York: Nova Science Publishers, Inc. 